\title{
Convergent Synthesis of Triazole Dendrimers via Click Chemistry Using Tripodal Core
}

\author{
Jae Wook Lee, Byung-Ku Kim, and Sung-Ho Jin ${ }^{\dagger}$ \\ Department of Chemistry, Dong-A University, Hadan-2-dong, Busan 604-714, Korea. *E-mail: jlee@dau.ac.kr \\ ${ }^{\dagger}$ Department of Chemistry Education \& Center for Plastic Information System, Pusan National University, Busan 609-735, Korea \\ Received February 19, 2005
}

Key Words : Click chemistry, Cycloaddition, Dendrimers, 1,2,3-Triazoles, Tripodal

\begin{abstract}
Azides and alkynes are among the least reactive functional groups and normally require prolonged heating to form the cycloaddition product. Recent investigation of the click chemistry, the $\mathrm{Cu}(\mathrm{I})$-catalyzed Huisgen $[2+3]$ dipolar cycloaddition reaction between an organic azide and an alkyne, has attracted attention. ${ }^{1}$ The reaction, characterized by very high yields, mild and simple reaction conditions, oxygen and water tolerance, and simple ways to product isolations, is highly chemoselective affording only the desired 1,2,3-triazole even in the presence of a large variety of other functional groups. The methodology has found many applications in organic chemistry, ${ }^{2}$ supramolecular chemistry, ${ }^{3}$ drug discovery, ${ }^{4}$ bioconjugations, ${ }^{5}$ and materials science. $^{6}$
\end{abstract}

Dendrimers are highly branched macromolecules, which are prepared by repetition of a given set of reactions using either divergent or convergent strategies. ${ }^{7}$ Generally, the reactions employed are high yielding without any side reactions. This then allows one to obtain defined and uniform structures. Well known processes, such as the Michael reaction, Williamson ether synthesis, amidations and reductions have been used extensively in pioneering work by Vögtle, Tomalia, Fréchet and Newkome. ${ }^{8}$ There are few reports to synthesize the triazole-mediated dendritic materials using click chemistry with dendronized azide. ${ }^{9}$ The most attractive feature of the convergent synthesis is that it requires few transformations per molecule in the coupling step. The reaction can be driven to completion with equivalent or only a slight excess of reagent, providing greater structural control in preparing well-defined (un)symmetrical dendrimers. Due to our interest in developing new dendrimers, we became involved in exploring efficient click reaction that provides an easy access to dendrimers. Here we present the convergent synthesis of triazole dendrimers by trimerization of acetylenic dendrons via click chemistry using tripodal core, 1,3,5-triazidomethylbenzene.

\section{Experimental Section}

General procedure for the preparation of acetylenicdendrons 2-Dn. $N, N$ '-Dicyclohexylcarbodiimide $(0.3$ $\mathrm{mmol})$ was added to a solution of propiolic acid $(0.3 \mathrm{mmol})$ and the corresponding dendritic benzyl alcohols $(0.3 \mathrm{mmol})$ in $\mathrm{CH}_{2} \mathrm{Cl}_{2}(5 \mathrm{~mL})$ at $5{ }^{\circ} \mathrm{C}$. The reaction mixture was stirred for $2 \mathrm{~h}$ at the same temperature and a further $12 \mathrm{~h}$ at room temperature. The resulting suspension was filtered and the filtrate was concentrated and purified by column chromatography $(\mathrm{EtOAc} / \mathrm{Hex})$ to afford the pure product 2-Dn.

2-D1: $90 \%$ yield; ${ }^{1} \mathrm{H}$ NMR $\left(300 \mathrm{MHz}, \mathrm{CDCl}_{3}\right) \delta 2.93$ (s, 1 H), 3.79 (s, $6 \mathrm{H}), 5.14$ (s, $2 \mathrm{H}), 6.43(\mathrm{~d}, J=2.3 \mathrm{~Hz}, 1 \mathrm{H}), 6.51$ $(\mathrm{d}, J=2.3 \mathrm{~Hz}, 2 \mathrm{H}) ;{ }^{13} \mathrm{C} \mathrm{NMR}\left(75 \mathrm{MHz}, \mathrm{CDCl}_{3}\right) \delta 161.0$, 152.5, 136.7, 106.3, 100.7, 75.4, 74.6, 67.8, 55.4; MS (EI): $m / z 220 \quad\left[\mathrm{M}^{+}\right], 167,151,139$; HRMS (EI) calcd for $\mathrm{C}_{12} \mathrm{H}_{12} \mathrm{O}_{4}: 220.0736$. found: 220.0732 .

2-D2: $75 \%$ yield; ${ }^{1} \mathrm{H}$ NMR $\left(300 \mathrm{MHz}, \mathrm{CDCl}_{3}\right) \delta 2.92(\mathrm{~s}, 1$ $\mathrm{H}), 3.78(\mathrm{~s}, 12 \mathrm{H}), 4.95(\mathrm{~s}, 4 \mathrm{H}), 5.12(\mathrm{~s}, 2 \mathrm{H}), 6.40(\mathrm{~m}, 2 \mathrm{H})$, $6.56(\mathrm{~m}, 5 \mathrm{H}), 6.59(\mathrm{~m}, 2 \mathrm{H}) ;{ }^{13} \mathrm{C} \mathrm{NMR}\left(75 \mathrm{MHz} \mathrm{CDCl}_{3}\right) \delta$ $161.1,160.1,152.5,139.1,136.8,107.4,105.3,102.3$, 100.0, 75.4, 74.6, 70.1, 67.7, 55.4; MS (EI): $m / z 492\left[\mathrm{M}^{+}\right]$, 413, 219, 195, 151, 113; HRMS (EI) calcd for $\mathrm{C}_{28} \mathrm{H}_{28} \mathrm{O}_{8}$ : 492.1784. found: 492.1786.

2-D3: $60 \%$ yield; ${ }^{1} \mathrm{H}$ NMR $\left(500 \mathrm{MHz}, \mathrm{CDCl}_{3}\right) \delta 2.89$ (s, 1 H), 3.78 (s, $24 \mathrm{H}), 4.97(\mathrm{~s}, 12 \mathrm{H}), 5.13(\mathrm{~s}, 2 \mathrm{H}), 6.40(\mathrm{~m}, 4$ $\mathrm{H}), 6.56(\mathrm{~m}, 13 \mathrm{H}), 6.66(\mathrm{~m}, 4 \mathrm{H}) ;{ }^{13} \mathrm{C} \mathrm{NMR}(125 \mathrm{MHz}$, $\left.\mathrm{CDCl}_{3}\right) \delta 161.1,160.2,160.1,152.6,139.3,139.2,136.9$, 107.5, 106.5, 105.4, 102.3, 101.8, 100.1, 75.4, 74.6, 70.2,

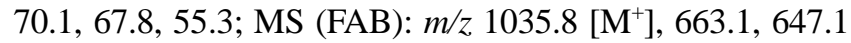
422.9, 391.0; HRMS (FAB) calcd for $\mathrm{C}_{60} \mathrm{H}_{60} \mathrm{O}_{16}: 1036.3881$. found: $1059.3778\left[\mathrm{M}^{+}+\mathrm{Na}\right]$.

General procedure for the preparation of 1,2,3-triazole dendrimers 3-Gn by reaction between tripodal azide 1 and acetylenic-dendrons 2-Dn. A mixture of 1,3,5triazidomethylbenzene $e^{10} \mathbf{1}(0.05 \mathrm{mmol})$ and acetylenicdendrons 2-Dn $(0.15 \mathrm{mmol})$ in toluene in the presence of $\mathrm{CuI}$ was stirred at $50-60{ }^{\circ} \mathrm{C}$. The reaction was monitored by TLC regarding on the disappearance of 2-Dn. The mixture was cooled to room temperature and then normal workup was carried out. The desired product was isolated by column chromatography.

3-G1: ${ }^{1} \mathrm{H}$ NMR $\left(500 \mathrm{MHz}, \mathrm{CDCl}_{3}\right) \delta 3.78(\mathrm{~s}, 18 \mathrm{H}), 5.31$ (s, $6 \mathrm{H}), 5.53(\mathrm{~s}, 6 \mathrm{H}), 6.42(\mathrm{~s}, 3 \mathrm{H}), 6.58(\mathrm{~s}, 6 \mathrm{H}), 7.16$ (s, 3 $\mathrm{H}), 8.03(\mathrm{~s}, 3 \mathrm{H}) ;{ }^{13} \mathrm{C} \mathrm{NMR}\left(75 \mathrm{MHz}, \mathrm{CDCl}_{3}\right) \delta 160.9$, 160.2, 140.0, 137.6, 136.4, 128.3, 128.2, 106.3, 100.1, 66.7, 55.3, 53.3; MS (FAB): $m / z 903.8\left[\mathrm{M}^{+}\right]$; HRMS (FAB) calcd for $\mathrm{C}_{45} \mathrm{H}_{45} \mathrm{~N}_{9} \mathrm{O}_{12}$ : 903.3188. found: 903.3184 .

3-G2: ${ }^{1} \mathrm{H}$ NMR $\left(300 \mathrm{MHz}, \mathrm{CDCl}_{3}\right) \delta 3.75(\mathrm{~s}, 36 \mathrm{H}), 4.91$ $(\mathrm{s}, 12 \mathrm{H}), 5.24(\mathrm{~s}, 6 \mathrm{H}), 5.46(\mathrm{~s}, 6 \mathrm{H}), 6.37(\mathrm{~m}, 6 \mathrm{H}), 6.53(\mathrm{~m}$, $15 \mathrm{H}), 6.61(\mathrm{~m}, 6 \mathrm{H}), 7.16(\mathrm{~s}, 3 \mathrm{H}), 8.02(\mathrm{~s}, 3 \mathrm{H}) ;{ }^{13} \mathrm{C} \mathrm{NMR}$ 
$\left(75 \mathrm{MHz}, \mathrm{CDCl}_{3}\right) \delta 161.1,160.2,160.1,140.4,139.1,137.8$, $136.6,128.11,128.05,107.5,105.4,102.0,100.0,70.1$, 66.8, 55.5, 53.5; MS (FAB): $m / z 1720.8\left[\mathrm{M}^{+}\right], 1743.1\left[\mathrm{M}^{+}+\right.$ $\mathrm{Na}$; HRMS (FAB) calcd for $\mathrm{C}_{93} \mathrm{H}_{93} \mathrm{~N}_{9} \mathrm{O}_{24}: 1719.6334$. found: 1719.6314 .

3-G3: ${ }^{1} \mathrm{H}$ NMR $\left(300 \mathrm{MHz}, \mathrm{CDCl}_{3}\right) \delta 3.75(\mathrm{~s}, 72 \mathrm{H}), 4.92$ $(\mathrm{s}, 36 \mathrm{H}), 5.25(\mathrm{~s}, 6 \mathrm{H}), 5.35(\mathrm{~s}, 6 \mathrm{H}), 6.37(\mathrm{~m}, 18 \mathrm{H}), 6.49$ (m, $6 \mathrm{H}), 6.54(\mathrm{~m}, 27 \mathrm{H}), 6.62(\mathrm{~m}, 12 \mathrm{H}), 7.06$ (s, $3 \mathrm{H}), 7.90$ $(\mathrm{s}, 3 \mathrm{H}) ;{ }^{13} \mathrm{C} \mathrm{NMR}\left(125 \mathrm{MHz}, \mathrm{CDCl}_{3}\right) \delta 161.0,160.1,160.0$, $140.3,139.2,139.1,137.7,136.4,128.0,127.8,107.3$, 106.4, 106.3, 105.3, 102.0, 101.6, 99.9, 70.0, 66.6, 55.5, 53.4; MS (FAB): $\mathrm{m} / z$ 3354.6 $\left[\mathrm{M}^{+}\right]$; HRMS (FAB) calcd for $\mathrm{C}_{189} \mathrm{H}_{189} \mathrm{~N}_{9} \mathrm{O}_{48}$ : 3352.2625. found: 3352.2604.

\section{Results and Discussion}

The synthetic strategy for triazole dendrimers 3-Gn utilized a convergent method using tripodal azides $\mathbf{1}$ and Fréchet-type acetylenic-dendrons 2-Dn (Scheme 1). The Fréchet-type acetylenic-dendrons 2-Dn $(\mathrm{n}=1,2$, and 3 : generation of dendron) were synthesized by DCC coupling of propiolic acid and the corresponding dendritic benzyl alcohols (Figure 1).

To test the effectiveness of the dipolar cycloaddition reactions of tripodal azide $\mathbf{1}$ and acetylenic-dendrons 2-Dn, we have reacted 1 with 2-D1 in toluene. The cycloadduct 3G1, which can be seen as first generation dendrimer was obtained in good yield contaminated with dendritic isomer having 1,5-disubstituted 1,2,3-triazole units. The reaction could be checked by IR spectroscopy by following the disappearance of the $\mathrm{N}_{3}$ stretching band at around 2100 $\mathrm{cm}^{-1}$. The generation and disappearance of the intermediates, which are mono- and/or di-triazole derivatives, were monitored by TLC runs of the reaction mixture. Both the 1,4- and 1,5-isomers of 1,2,3-triazole moiety, known to be generated from the azide and acetylene reaction, ${ }^{11}$ were also formed in the reactions of 2-D1 with benzyl azide (Scheme 2). At $80{ }^{\circ} \mathrm{C}$ in toluene the reaction provided the 1,2,3-triazole product in $93 \%$ yield with the 1,4- to 1,5isomers in the ratio of $\sim 3: 1{ }^{12}$ To reduce the generation of 1,5-disubstituted 1,2,3-triazole units in the dendrimers, we adapted a literature procedure, where the role of $\mathrm{Cu}(\mathrm{I})$

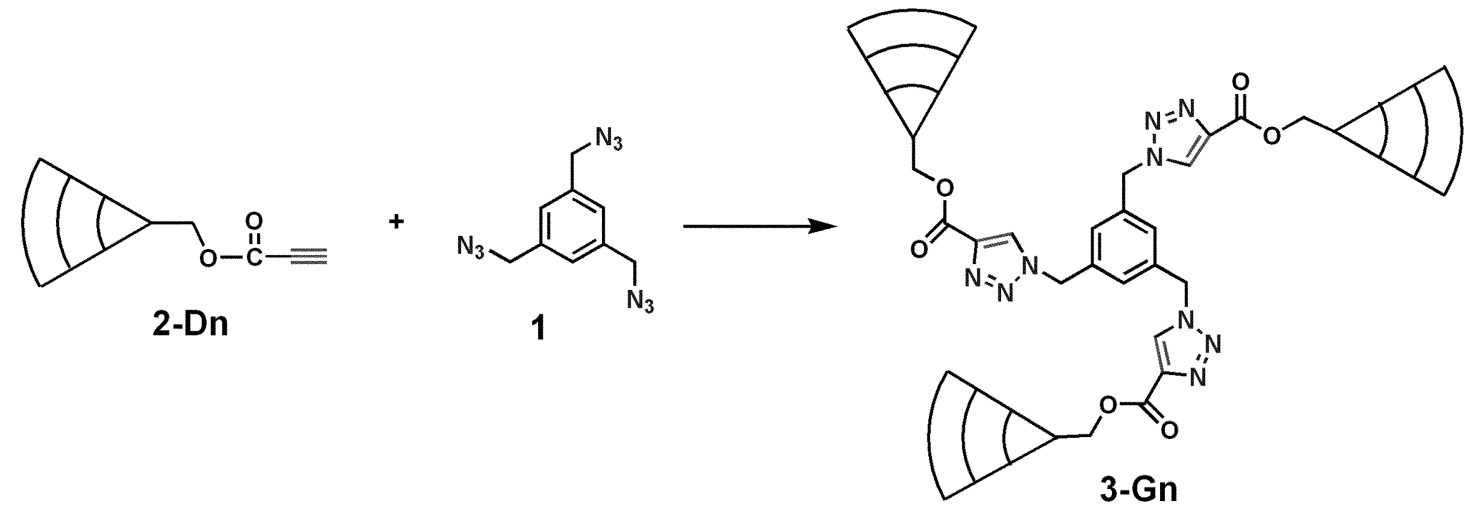

Scheme 1. Synthetic strategy of triazole dendrimers by trimerization. Reaction condition: toluene, $\mathrm{CuI}, 50{ }^{\circ} \mathrm{C}$.

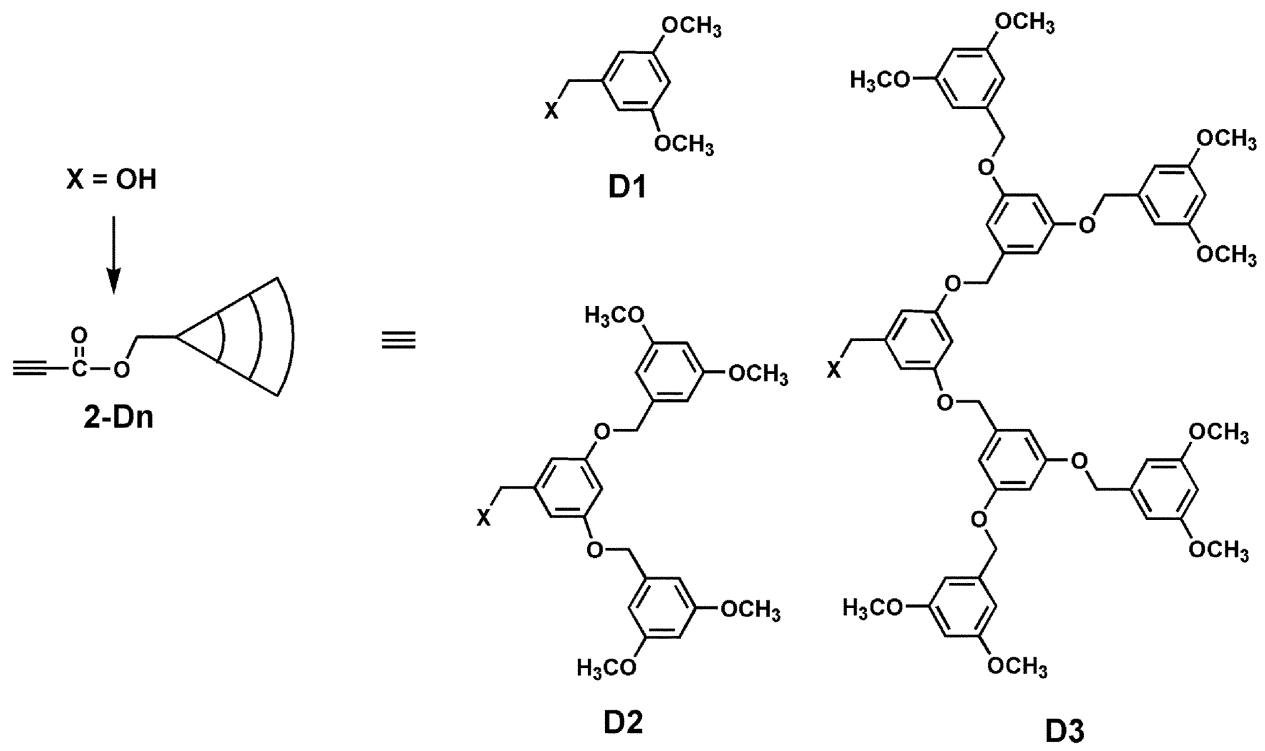

Figure 1. Structures of acetylenic-dendrons 2-Dn. 
<smiles>C#CC(=O)OCc1cc(OC)cc(OC)c1</smiles><smiles>COc1cc(COC(=O)c2cn(Cc3ccccc3)nn2)cc(OC)c1</smiles>

1,4-isomer<smiles>COc1cc(COC(=O)c2cnnn2Cc2ccccc2)cc(OC)c1</smiles>

Scheme 2. Cycloaddition reaction of benzyl azide with acetylenicdendron 2-D1. Reaction condition: toluene, $80{ }^{\circ} \mathrm{C}, 30 \mathrm{~h}$ or toluene, $\mathrm{CuI}, 50^{\circ} \mathrm{C}, 48 \mathrm{~h}$.

species in Huisgen [2+3] dipolar cycloaddition reaction has been proved to influence the regioselective product distribution. ${ }^{13}$ The reaction of 2-D1 with benzyl azide in the presence of $\mathrm{CuI}$ at $50{ }^{\circ} \mathrm{C}$ in toluene provided the 1,2,3triazole product in $95 \%$ yield with $\sim 8: 1$ ratio of $1,4-$ to $1,5-$ isomer.
To synthesize the triazole dendrimers, we investigated the reactions of tripodal azide 1 with acetylenic-dendrons 2-D1 in the presence of $\mathrm{CuI}$ at various temperature in solvents such as toluene, THF, DMF, and THF-toluene mixture. The reaction conducted at $50{ }^{\circ} \mathrm{C}$ in toluene provided the most satisfying result and led to the first generation triazole dendrimer. With this optimized reaction condition, we synthesized the triazole dendrimers by the trimerization reactions between tripodal azide $\mathbf{1}$ and acetylenic-dendrons 2-Dn. The reaction of $\mathbf{1}$ with 2-D1 in the presence of $\mathrm{CuI}$ at $50{ }^{\circ} \mathrm{C}$ in $0.05 \mathrm{M}$ solution in toluene provided the triazole dendrimer 3-G1 having just 1,4-disubstituted 1,2,3-triazole units in $59 \%$ yield. Other isomeric products of the reaction are the triazole dendrimers containing two 1,4-disubstituted 1,2,3-triazole units and one 1,5-disubstituted 1,2,3-triazole unit $(\sim 18 \%)$, and a 1,4-disubstituted 1,2,3-triazole unit and two 1,5-disubstituted 1,2,3-triazole units $(\sim 3 \%)$. The same reaction conducted in $0.015 M$ concentration afforded the desired product 3-G1 in 70\% yield and reduced the generation of isomeric triazole dendrimers. ${ }^{14}$

Next, we conducted the reaction in diluted solution to suppress the generation 1,5-isomer unit(s) and remove the solubility problem of dendritic intermediate(s) in the construction of higher generation dendrimers. The reaction of 1 with 2-D2 in the presence of $\mathrm{CuI}$ at $50{ }^{\circ} \mathrm{C}$ in $0.008 \mathrm{M}$ solution in toluene provided the triazole dendrimer 3-G2 in $79 \%$ yield having only 1,4-disubstituted 1,2,3-triazole units and tiny amount of the triazole dendrimers containing two<smiles>COc1cc(COc2cc(COc3cc(COc4cc(COc5cc(COc6cc(COc7cc(OCc8cc(OC)cc(OC)c8)cc(OCc8cc(OC)cc(OC)c8)c7)cc(OCc7cc(OCc8cc(OC)cc(OC)c8)cc(OCc8cc(OC)cc(OC)c8)c7)c6)cc(OCc6cc(OCc7cc(OC)cc(OC)c7)cc(OCc7cc(OC)cc(OC)c7)c6)c5)cc(OCc5cc(OCc6cc(OC)cc(OC)c6)cc(OCc6cc(OC)cc(OC)c6)c5)c4)cc(OCc4cc(OCc5cc(OC)cc(OC)c5)cc(OCc5cc(OC)cc(OC)c5)c4)c3)cc(OC)c2)cc(OC)c1</smiles>

Figure 2. Structure of the third generation of triazole dendrimer 3-G3. 
1,4-disubstituted 1,2,3-triazole units and one 1,5-disubstituted 1,2,3-triazole unit. These observations suggested that the $\mathrm{Cu}(\mathrm{I})$ species, steric effect of the dendron, and kinetic factors controlled by concentration are crucial in the formation of the desired 1,4-disubstituted 1,2,3-triazole dendrimer. The reaction of $\mathbf{1}$ with the third generation dendron 2-D3 in the presence of $\mathrm{CuI}$ at $50{ }^{\circ} \mathrm{C}$ in $0.002 \mathrm{M}$ toluene solution provided the third generation triazole dendrimer 3-G3 in 66\% yield having only 1,4-disubstituted 1,2,3-triazole units without any isomeric dendritic components. This observation indicates that the steric hindrance of dendron is important factor in ruling out the generation of 1,5-isomeric unit in trimerization reaction between tripodal azide and dendrons. Thus, the formation of triazole between tripodal azide and acetylenic dendrons can be regarded as a new approach to construct various dendrimers.

All compounds were confirmed by ${ }^{1} \mathrm{H}$ and ${ }^{13} \mathrm{C}$ NMR spectroscopy and exhibited very good correlation with the calculated molecular masses as evidenced by their FAB mass spectra. From their ${ }^{1} \mathrm{H}$ NMR spectra $\left(\mathrm{CDCl}_{3}\right)$, the peaks of the benzene protons of core and the triazole protons in dendrimers 3-Gn were found at 7.16 and 8.03 ppm for 3G1, 7.16 and 8.02 ppm for 3-G2, and 7.06 and 7.90 ppm for 3-G3, respectively. As the dendrimer generation increased, the peaks of the benzene protons of core and the triazole protons showed up-field shift. In third generation dendrimer (Figure 2) it is observed that the benzene protons of core and the triazole protons are influenced by the larger dendritic effect changing their microenvironment.

In summary, we have demonstrated that the trimerization reactions between tripodal azide and acetylenic dendrons lead to the formation of 1,4-disubstituted triazole dendrimers in high yields. Furthermore, it is found that the presence of $\mathrm{Cu}(\mathrm{I})$ species, steric effect of the dendron, and kinetic factors controlled by concentration are crucial in higher yields of the 1,4-disubstituted 1,2,3-triazole dendrimer. This unique reaction may provide an insight into designing various symmetrical dendrimers. We are currently working towards various functional dendrimers using this strategy for various applications, such as the templated synthesis of nanomaterials.

Acknowledgement. This research was supported by the MIC, Korea, under the ITRC support program supervised by the IITA. We thank Prof. S. Samal for reading the manuscript.

\section{References and Notes}

1. Kolb, H. C.; Finn, M. G.; Sharpless, K. B. Angew. Chem. Int. Ed. 2001, 40, 2004.

2. (a) Katritzky, A. R.; Zhang, Y.; Singh, S. K. Heterocycles 2003 , 60, 1225. (b) Wang, Z.-X.; Qin, H.-L. Chem. Commun. 2003, 2450. (c) Jin, T.; Kamijo, S.; Yamamoto, Y. Eur. J. Org. Chem.
2004, 3789 .

3. (a) Badjiæ, J. D.; Balzani, V.; Credi, A.; Lowe, J. N.; Silvi, S.; Stoddart, J. F. Chem. Eur. J. 2004, 10, 1926. (b) Lee, J. K.; Chi, Y. S.; Choi, I. S. Langmuir 2004, 20, 3844. (c) Collman, J. P.; Devaraj, N. K.; Chidsey, C. E. D. Langmuir 2004, 20, 1051. (d) Chi, Y. S.; Lee, J. K.; Lee, K.-B.; Kim, D. J.; Choi, I. S. Bull. Korean Chem. Soc. 2005, 26, 361.

4. (a) Lenda, F.; Guenoun, F.; Tazi, B.; Larbi, N. B.; Martinez, J.; Lamaty, F. Tetrahedron Lett. 2004, 45, 8905. (b) Manetsch, R.; Krasiñski, A.; Radiæ, Z.; Raushel, J.; Taylor, P.; Sharpless, K. B.; Kolb, H. C. J. Am. Chem. Soc. 2004, 126, 12809. (c) Kolb, H. C.; Sharpless, K. B. Drug Discovery Today 2003, 8, 1128.

5. (a) Wang, Q.; Chan, T. R.; Hilgraf, R.; Fokin, V. V.; Sharpless, K. B.; Finn, M. G. J. Am. Chem. Soc. 2003, 125, 3192. (b) Meng, J.C.; Siuzdak, G.; Finn, M. G. Chem. Commun. 2004, 2108. (c) Link, A. J.; Vink, M. K. S.; Tirrell, D. A. J. Am. Chem. Soc. 2004, 126, 10598. (d) Sivakumar, K.; Xie, F.; Cash, B. M.; Long, S.; Barnhill, H. N.; Wang, Q. Org. Lett. 2004, 6, 4603 and references therein.

6. Díaz, D. D.; Punna, S.; Holzer, P.; McPherson, A. K.; Sharpless, K. B.; Fokin, V. V.; Finn, M. G. J. Polym. Sci., Part A 2004, 42, 4392.

7. Grayson, S. M.; Fréchet, J. M. J. Chem. Rev. 2001, 101, 3919.

8. (a) Newkome, G. R.; Moorefield, C. N.; Vögtle, F. Dendrimers and Dendrons: Concepts, Synthesis, Applications; Wiley-VCH: Weinheim, 2001. (b) Choi, J. S.; Choi, Y. H.; Park, J. S. Bull. Korean Chem. Soc. 2004, 25, 1025. (c) Kim, T.-i.; Jang, H.-S.; Joo, D. K.; Choi, J. S.; Park, J.-S. Bull. Korean Chem. Soc. 2003, $24,123$.

9. (a) Wu, P.; Feldman, A. K.; Nugent, A. K.; Hawker, C. J.; Scheel, A.; Voit, B.; Pyun, J.; Fréchet, J. M. J.; Sharpless, K. B.; Fokin, V. V. Angew. Chem. Int. Ed. 2004, 43, 3928. (b) Helms, B.; Mynar, J. L.; Hawker, C. J.; Fréchet, J. M. J. J. Am. Chem. Soc. 2004, 126, 15020. (c) Wuytswinkel, G. V.; Verheyde, B.; Compernolle, F.; Toppet, S.; Dehaen, W. J. Chem. Soc., Perkin Trans. 1 2000, 1337. (d) Lee, J. W.; Kim, B. K. Bull. Korean Chem. Soc. 2005, 26, 658.

10. Heyer, H.; Lehn, J. M. Tetrahedron Lett. 1986, 27, 5869.

11. Huisgen, R. In 1,3-Dipolar Cycloaddition Chemistry; Padwa, A., Ed.; Wiley: New York, 1984; Vol. 1, pp 1-176.

12. Each isomer can be separated by column chromatography and distinguished by their ${ }^{1} \mathrm{H}$ NMR spectra $\left(\mathrm{CDCl}_{3}\right)$ that the triazole proton of 1,4-regioisomer was found at $7.97 \mathrm{ppm}$ and in the corresponding 1,5-isomer it was shifted downfield to $8.17 \mathrm{ppm}$. For 1,4-regioisomer: ${ }^{1} \mathrm{H}$ NMR $\left(200 \mathrm{MHz}, \mathrm{CDCl}_{3}\right) \delta 3.77(\mathrm{~s}, 6 \mathrm{H})$, $5.29(\mathrm{~s}, 2 \mathrm{H}), 5.56(\mathrm{~s}, 2 \mathrm{H}), 6.41(\mathrm{~m}, 1 \mathrm{H}), 6.57(\mathrm{~m}, 2 \mathrm{H}), 7.27(\mathrm{~m}$, $2 \mathrm{H}), 7.38(\mathrm{~m}, 3 \mathrm{H}), 7.97(\mathrm{~s}, 1 \mathrm{H}) ;{ }^{13} \mathrm{C} \mathrm{NMR}\left(50 \mathrm{MHz}, \mathrm{CDCl}_{3}\right) \delta$ $160.9,158.1,138.5,138.3,136.7,134.8,128.7,128.4,128.0$, 106.2, 100.3, 67.2, 55.3, 53.5. For 1,5-regioisomer: ${ }^{1} \mathrm{H}$ NMR $(200$ $\left.\mathrm{MHz}, \mathrm{CDCl}_{3}\right) \delta 3.78(\mathrm{~s}, 6 \mathrm{H}), 5.23(\mathrm{~s}, 2 \mathrm{H}), 5.92(\mathrm{~s}, 2 \mathrm{H}), 6.45(\mathrm{~m}$, $1 \mathrm{H}), 6.50(\mathrm{~m}, 2 \mathrm{H}), 7.30(\mathrm{~m}, 5 \mathrm{H}), 8.17(\mathrm{~s}, 1 \mathrm{H}) ;{ }^{13} \mathrm{C}$ NMR $(50$ $\left.\mathrm{MHz}, \mathrm{CDCl}_{3}\right) \delta 160.8,160.3,140.0,137.5,133.6,129.1,128.2$, 127.5, 127.3, 106.2, 100.2, 66.6, 55.3, 54.3.

13. (a) Rostovtsev, V. V.; Green, L. G.; Fokin, V. V.; Sharpless, K. B. Angew. Chem. Int. Ed. 2002, 41, 2596. (b) Tornøe, C. W.; Christensen, C.; Meldal, M. J. Org. Chem. 2002, 67, 3057. (c) Fazio, F.; Bryan, M. C.; Blixt, O.; Paulson, J. C.; Wong, C.-H. J. Am. Chem. Soc. 2002, 124, 14397.

14. In addition to the desired product, the triazole dendrimer containing two 1,4-disubstituted 1,2,3-triazole units and one 1,5disubstituted 1,2,3-triazole unit was obtained in $~ 9 \%$ yield wheares the triazole dendrimer having a 1,4-disubstituted 1,2,3triazole unit and two 1,5-disubstituted 1,2,3-triazole units was not found. 